O-125鼻性NK/T細胞リンパ腫におけるCDK1とサバ イビンの発現

○長門 利純, 上田 征吾, 岸部幹, 高原 幹, 原㴊保明

旭川医科大学耳鼻咽喉科・頭頸部外科

鼻性NK/T細胞リンパ腫では EBウイルス2型潜伏感染 を呈し, ウイルス関連蛋白であるLMP1を発現すること で発癌に関与するとされる。また, 本疾患での生検腫瘍 組織における遺伝子発現プロファイリングの検討で, CDK1とサバイビンの発現立進が指摘され，それらはそ れぞれ細胞周期促進とアポトーシス抑制により細胞増殖 に関与していると考えられている。しかし，本疾患にお けるLMP1とCDK1ならびにサバイビンの関連について はわかっていない。今回われわれは, 本疾患細胞株を用 いてLMP1をsiRNAでノックダウンしたところ, CDK1 およびサバイビンの発現低下を認めた。また, 本疾患腫 瘍組織での免疫組織化学染色において, LMP1とCDK1 もしくはサバイビンの共陽性細胞を認めた。本腫瘍細胞 株に対するCDK1およびサバイビン阻害薬を用いた検討 では，濃度依存性に増殖抑制効果を認めた。以上より LMP1はCDK1ならびにサバイビンの発現を介して細胞 増殖に関与することが示唆された。さらに, 本疾患細胞 株を皮下移植した異種移植マウスモデルを用いて, CDK1とサバイビンの作用を抑制するミトラマイシン A を投与し抗腫瘍効果を検討した。その結果, ミトラマイ シンAを投与された治療群は未治療群と比較して有意に 腫瘍増殖が抑制された。以上より, CDK1とサバイビン をターゲットとした治療は, 予後不良な本疾患の治療選 択肢となりうることが期待された。

\section{O-126 当科で入院加療を行った鼻出血例の検討}

○栗山 達朗, 乾崇樹, 鈴木 倫雄, 鈴木 学, 寺田哲也, 河田了

大阪医科大学耳鼻咽喉科・頭頸部外科

鼻出血は外来での止血処置により制御可能であること が多いが, 難治例, 特に後方出血例では入院, 手術での 加療を余儀なくされることもある。

今回われわれは，過去 4 年間に当科で入院加療を行っ た鼻出血例52例（男性37例，女性15例）を対象とし，そ の難治化因子や出血点別の手術成績などについて考察 した。対象は特発性鼻出血のみとし, 年齢は $22 \sim 89$ 歳 (平均63.4歳) であった。

52 例中 29 例に対し, 手術室にて全身麻酔下の鼻内内視 鏡手術による止血術を行った。当科での鼻出血に対する 手術適応は診察室での鼻内ガーゼ挿入による止血処置が 複数回に上り，かつ原則として外頸動脈系からの出血が 疑われる症例とし，内視鏡下での出血点の検索と止血処 置, 粘膜下での蝶口蓋動脈の電気焼灼を行っている。

高血圧などの血液循環系に関係しうる合併症は, 手術 例, 非手術例ともに17例ずつ, 抗凝固薬服用例は手術例 7 例, 非手術例 8 例でありともに有意な差を認めなかった。

出血点の入院時評価は, 内頸動脈系 12 例, 外頸動脈系 5例，不明35例であった。このうち手術例では，術前の 評価は内頸動脈系 2 例, 外頸動脈系2例, 不明 25 例であっ た。術中所見により出血点は内頸動脈系11例，外頸動脈 系7例が判明したが，11例では不明のままであった。手 術例と非手術例での判明した出血部位を比較すると, 内 頸動脈系由来, 外頸動脈系由来であるかに有意差は見ら れなかった。なお，2例で術後に再出血を来したが，1例 が逆側，1例が同側からの出血であった。逆側からの出 血例では再手術をし, 内頸動脈系からの出血を認めた。 同側からの出血例では出血点は不明のままであったが, 再々手術は要しなかった。

以上から, 難治性の鼻出血例において, 出血点が把握 出来ていないことが入院あるいは手術加療を要する一因 であると考えられた。また，これらの症例に対して積極 的に手術を行うことは, 出血を制御する有効な手段であ ると考えられた。 
O-127 遺伝性出血性末梢血管拡張症に対する Bevacizumabの使用経験

○山内 智彦 ${ }^{1}$, 歌野 健一 ${ }^{2}$, 横山 秀二 ${ }^{1}$, 小川 洋 $^{1}$

1福島県立医科大学会津医療センター耳鼻咽喉科学講座 2 福島県立医科大学会津医療センター小腸大腸肛門科学講座

遺伝性出血性末梢血管拡張症（Hereditary Hemorrhagic Teleangiectasia: HHT) は常染色体優性遺伝形式をとる 全身の粘膜, 皮膚, 内臓，中枢神経などの血管奇形病変 である。鼻出血，消化管出血，喀血，呼吸困難，全身倦 意感，頭痛，けいれんなどの症状を呈し，発症率は5,000〜 8,000 人に 1 人と言われている。鼻出血に対しては鼻腔へ のガーゼパッキングや焼灼術（レーザー, 電気, アルゴ ンプラズマ凝固装置など), 血管塞栓術の他, 各種薬剤 （トラネキサム酸，エストロゲン製剤， $\beta$ 遮断薬）も用い られている。重症例には鼻粘膜皮膚置換術や外鼻孔閉 鎖術なども行われている。今回HHTの鼻出血, 消化 管出血に対して，ヒト血管内皮増殖因子（Vascular Endothelial Growth Factor: VEGF) に対する遺伝子組 み換え型モノクローナル抗体であるBevacizumabを用 いたので, その経験を報告する。症例は74歳男性。父親 に習慣性鼻出血の既往あり。本人は20歳頃より鼻出血あ り。H24年より骨䯣異形成症候群で当院血液内科通院中 であった。平成 25 年7月鼻出血で当科初診。鼻出血が頻 回で合計9回の当科入院歴あり。鼻粘膜焼灼術や輸血も 頻回に施行した。回盲部の潰瘍・多発血管拡張病変によ る下血も頻回で, 平成 26 年 2 月回盲部切除術を施行した。 術後も吻合部近辺からの出血あり。鼻出血と消化管出血 の制御目的に倫理委員会での承認を得て平成27年9月よ りBevacizumabを投与した。1回量 $100 \mathrm{mg}$ (約 $2 \mathrm{mg} / \mathrm{kg}$ ) を経静脈的に3週間間隔で3回投与した。薬効をAl-Dean らの尺度で評価した。投与直前はI4F1T2, 最終投与後
O-128 遺伝性出血性毛細血管拡張症（HHT）関連鼻 出血に対するエストリオール軟言の治療効果

○福田有里子 ${ }^{1}$, 高原 慎一 ${ }^{2}$, 藤尾 久美, 井之口 豪 ${ }^{1}$, 古閑 紀雄 ${ }^{1}$, 丹生 健一 ${ }^{1}$

1神戸大学大学院医学研究科外科系講座耳鼻咽喉科 . 頭頸部外科学分野

加古川西市民病院耳鼻咽喉科

【背景】遺伝性出血性毛細血管拡張症（オスラー病, 以 下HHT）は毛細血管の拡張や動静脈奇形といった血管 奇形を呈する疾患であり，反復する鼻出血を主訴に耳鼻 咽喉科を受診することが多い。本邦ではレーザーや電気 凝固による粘膜焼灼術が中心に行われ，重症例では皮䖉 粘膜置換術や外鼻孔閉鎖術も行われる。しかし実際には, 鼻出血の管理に難渋することが多い。HHT関連鼻出血 に対する女性ホルモン療法に関しては，2003年にSadick らがエストロゲンの鼻粘膜局所投与による鼻出血の軽減 効果を報告している。【方法】HHT関連鼻出血に対する エストリオール軟亮の臨床治験を計画し, 院内倫理委員 会の承認を得て，2015年6月から開始した。臨床治験に おいては, HoagらのHHT鼻出血重症度スコアを用いて, 鼻出血の頻度, 出血時間, 輸血の有無などの項目につい て10点満点で評価し，経時変化を観察している。昨年の 報告では, 鼻出血回数, 持続時間ともに低下したものの, 血中エストリオール值の上昇が問題となっていた。しか し，休薬後1-2か月でほとんどの症例でエストリオール 值は正常值化した。血中エストリオール值の正常化を確 認後, 2016年1月より基剤のワセリンを順次変更し, 投 与量を半分に減らすことで, 全身への影響を減らす試み を行っている。【結果】今回の発表では, 新たに参加し た症例を含め, エストリオール軟膏治療の長期成績と副 作用について報告する。 
O-129 オスラー病に伴う鼻出血に対する鼻粘膜焼灼術 の検討

○赤澤 仁司 ${ }^{1,2}$, 岡崎 鈴代 ${ }^{2}$, 識名 崇 ${ }^{1}$, 端山 昌樹 ${ }^{2}$, 前田 陽平 ${ }^{2}$, 猪原 秀典 ${ }^{2}$

${ }^{1}$ 市立池田病院耳鼻いんこう科

${ }^{2}$ 大阪大学医学部附属病院耳鼻咽喉科 · 頭頸部外科

オスラー病（遺伝性出血性末梢血管拡張症）は, 皮膚・ 粘膜の毛細血管拡張や多臓器の動静脈奇形を特徵とする 常染色体優性遺伝疾患で, 鼻出血. 奇異性脳塞栓 - 消化 管出血などの症状を呈する。軽微な刺激で出血が起こり やすく, 反復性鼻出血に悩まされる患者が多い。オスラー 病による鼻出血に対する手術治療としては, 粘膜焼灼術 や皮膚粘膜置換術, 鼻孔閉鎖術がある。粘膜焼灼には, 電気凝固は鼻中隔穿孔をきたし，コントロール不良とな るため禁忌とされ, KTPレーザーがgold standardとさ れてきた。最近では低温凝固でき周辺臓器への損傷の少 ない高周波電気凝固装置（コブレーター）を用いた報告 も散見される。今回, 当施設及び大阪大学医学部附属病 院でオスラー病（臨床診断基準で2項目以上満たした確 実例および疑い例）に伴う鼻出血に対して，2013年7月 以降に鼻粘膜焼灼術を8例18件施行した。当初はKTP レーザーを用いていたが，術中の止血困難例が散見され たため，2014年3月からはコブレーターも用いている。 コブレーター導入後は, KTPレーザー無効症例も含め て全例で良好なコントロールが得られており，鼻中隔穿 孔の合併も認めていない。コブレーターを用いた手術動 画を供覧し, 治療成績を報告する。また合併症や診断経 過についても検討し，報告する。

\section{O-130 小児上顎逆性過剰歯症例の検討}

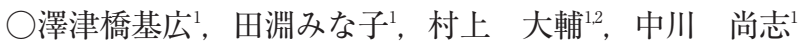
${ }^{1}$ 九州大学大学院医学研究院耳鼻咽喉科頭頸部外科 2福岡県済生会福岡総合病院耳鼻咽喉科頭頸部外科

【目的】上顎正中部の逆生埋伏過剩歯については, 多く の報告がなされているが, 耳鼻咽喉科の診療において遭 遇する頻度は極めて低い。しかし, 逆生埋伏過剩歯は自 然に口腔内に萌出することはなく, むしろ鼻腔側へ萌出 する可能性があり，上顎洞内過剩逆生歯牙症例や鼻腔内 過剩歯牙症例が過去においても報告されている。今回 我々は, 当院小児歯科より相談を受け, 小児上顎逆性過 剩歯症例の4例を経験し, 耳鼻咽喉科としての対応につ いて検討したので報告する。【対象症例】症例は, 上顎 逆性埋没過剩歯3例, 鼻腔内逆生過剩歯1例である。全て 男児で, 初診時年齢は6歳から10歳, 平均8歳であった。 上顎逆性埋没過剩歯3例の受診機転は, 歯並び, 両上顎 2 番の萌出遅延, 歯科衛生指導中の偶然の指摘であっ た。鼻腔内逆生歯症例は, 繰り返す膿性鼻漏であった。 【治療法】上顎逆性埋没過剩歯の2例は, 経口腔的に過剩 歯摘出術が行われた。その際，鼻腔底への穿孔が懸念さ れたが, 結果的に鼻腔粘膜は温存された。残り1例は, 梨状口縁の骨内に埋没しており，鼻腔，上顎洞及び歯列 への影響が無いため, 経過観察となった。鼻腔内逆生歯 症例は, 右鼻腔内に突出する犬歯状歯牙を認め, その周 囲には病的肉芽を認めた。全麻下に鼻内より内視鏡下に 鉗子を用いて過剩歯を摘出した。【考察】上顎逆性埋没 過剰歯については, 摘出手術の適応や時期については歯 科医の判断になるが，歯及び顎に明らかな異常がみられ ない症例は, 摘出手術は永久前歯の歯根形成の時期を避 け，適当な時期まで延期することが可能で，経過観察に なる場合もある。この際, 成長ともに歯根形成中に鼻腔 側へ顎骨内を移動する逆性埋没過剩歯症例もあり，注意 が必要である。鼻腔内逆生歯牙症例については, 過去の 報告によると, その症状は, 鼻閉, 鼻漏, 悪臭, 鼻出血 などで, 治療は, 鼻腔より摘出術が施行されている。 